\title{
BIEGUNKA PODRÓŻNYCH
}

\section{TRAVELLERS' DIARRHEA}

\author{
Ewelina Kimszal ${ }^{1}$, Katarzyna Van Damme-Ostapowicz ${ }^{2}$ \\ 1 Studenckie Koło Naukowe „Tropik” \\ Zakład Zintegrowanej Opieki Medycznej \\ Uniwersytet Medyczny w Białymstoku \\ 2 Zakład Zintegrowanej Opieki Medycznej \\ Uniwersytet Medyczny w Białymstoku
}

DOI: http://dx.doi.org/10.20883/pielpol.2016.16

\begin{abstract}
STRESZCZENIE
Szacuje się, że około 50 milionów osób z naszego kraju wyjeżdża rocznie do strefy tropikalnej. Biegunka podróżnych jest najczęstszym problemem zdrowotnym osób podróżujących z krajów uprzemysłowionych do krajów rozwijających się o niskim standardzie sanitarnym. Najczęstszą przyczyną biegunek jest zakażenie enterotoksycznym szczepem Escherichia coli. Niepoddana odpowiedniej obróbce żywność i zanieczyszczona fekaliami woda są głównym rezerwuarem patogenów wywołujących biegunki podróżnych. Podstawowe znaczenie w profilaktyce mają: dokładna higiena rąk, picie butelkowanej wody oraz odpowiednia obróbka termiczna produktów. Leczenie biegunki polega przede wszystkim na zapobieganiu odwodnieniu. Innym znanym sposobem jest terapia antybiotykami, loperamidem. W fazie badań naukowych są probiotyki i szczepionka WC-rBS stosowana w profilaktyce cholery. Głównym celem pracy jest zwiększenie świadomości społeczeństwa na temat problemów, jakie mogą przytrafić się nam podczas podróży; ponadto przybliżono podstawowe informacje na temat biegunki podróżnych takie jak: objawy, obszary występowania, możliwości zakażenia, leczenie oraz jaką zastosować profilaktykę, aby uniknąć nieprzyjemnych skutków podróżowania.
\end{abstract}

SŁOWA KLUCZOWE: biegunka, podróże, medycyna podróży, choroby tropikalne.

\section{Wprowadzenie}

W Polsce nie ma dokładnych danych na temat liczby osób wyjeżdżających do strefy tropikalnej. Mówi się, że co roku podróżuje około 50 milionów obywateli naszego kraju [1]. Jak wiadomo, podróżowanie to zmiana środowiska; wiążą się z tym zwiększone problemy zdrowotne zarówno podczas samej podróży, jak i w trakcie pobytu [2]. Szacuje się, że dotykają one 15-75\% osób wyjeżdżających do strefy tropikalnej [3]. Do takich problemów możemy zaliczyć ostrą infekcję przewodu pokarmowego, manifestującą się krótką i czasem trudną do opanowania biegunką, która w późniejszym okresie może nieprzyjemnie popsuć nam plany związane z wycieczką [4].

\begin{abstract}
It is estimated that about 50 million people in our country goes annually to the tropics. Travellers' diarrhea is the most common health problem of travelers from industrialized countries to developing countries with a low standard of sanitation. The most common cause of diarrhea is the infection by the entero-toxic strain of Escherichia coli. Food and water contaminated with feces are the main reservoir of pathogens that cause travellers' diarrhea. The basic importance in the prevention is an accurate hand hygiene, drinking bottled water and adequate thermal treatment products. Treatment of diarrhea is primarily to prevent dehydration. Another known method is the antibiotic treatment, loperamide. In the phase of research are probiotics and vaccine WC-RBS known in the prevention of cholera. The main aim is to increase public awareness of the problems that can appear during the trip to the tropics. The main aim is to increase public awareness about the problems that can happen to us when traveling, as well as learning basic information about travellers' diarrhea, such as symptoms, areas of occurrence, the possibility of infection, treatment, and how to use prevention to avoid unpleasant effects of travel.
\end{abstract}

KEYWORDS: diarrhea, travels, travel medicine, tropical diseases.

\section{Co to jest biegunka podróżnych i jak się objawia?}

Biegunka podróżnych (ang. travellers' diarrhea - TD) jest najczęstszym problemem zdrowotnym osób podróżujących z krajów uprzemysłowionych do krajów rozwijających się o niskim standardzie sanitarnym. Kraj (rejon) pobytu jest czynnikiem przyczyniającym się do ryzyka wystąpienia biegunki podróżnych. Szacuje się, że występuje ona u 30-70\% osób wyjeżdżających. Z problemem tym borykają się od lat nie tylko cywile, narażeni są również wojskowi wyjeżdżający na misje. Brak odpowiedniej odporności na patogeny przyczynia się do wystąpienia choroby [5]. W 80\% przyczyną biegunek 
jest zakażenie enterotoksycznym szczepem Escherichia coli (ETEC), rzadziej do zakażenia dochodzi bakterią z rodzaju Campylobacter, Shigella, Salmonella [6]. Pasożyty i wirusy są mniej powszechne w etiologii. Wirusy (rotawirusy) stanowią zwykle 5-8\% zakażeń, pasożyty (Giardia lamblia, Cryptosporidium parvum, Entamoeba hystolytica) - łącznie około $10 \%$; objawy w tej grupie rozwijają się dłużej [7].

Ciężką biegunkę podróżnych rozpoznaje się u turysty, jeżeli w czasie wycieczki oddaje 3 i więcej płynnych lub półpłynnych stolców. Towarzyszy temu co najmniej jeden z wymienionych objawów: gorączka, nudności, wymioty, bóle brzucha, obecność krwi w kale lub bolesne parcie na stolec. O umiarkowanej TD mówimy, kiedy występują 1 lub 2 płynne lub półpłynne stolce w ciągu 24 godzin bez dodatkowych objawów. Łagodna biegunka podróżnych występuje, kiedy mamy 1 lub 2 płynne lub półpłynne stolce bez dodatkowych objawów i nie wpływają one na codzienne czynności życiowe. Biegunka zwykle przemija samoistnie po 3-4 dniach [8].

Zazwyczaj objawy pojawiają się w pierwszym tygodniu pobytu, a w ponad $90 \%$ przypadków występują w ciągu pierwszych 2 tygodni. Około 80\% turystów z biegunką skarży się na skurcze brzucha, 10-25\% ma gorączkę, 20\% ma wymioty, a od 5\% do 10\% ma krew lub śluz w kale. Biegunka podróżnych może spowodować znaczące zakłócenia, bo aż 40\% musi zmodyfikować swoje działania w jakiś sposób, a około $20 \%$ osób musi spędzić w łóżku 1 lub 2 dni. Pobyt w szpitalu jest rzadki i dotyczy do 1\% osób wyjeżdżających, śmiertelność w tej chorobie jest rzadka. Chociaż objawy w większości przypadków są krótkotrwałe, niestety zdarzają się incydenty, w których biegunka może trwać przez miesiąc lub dłużej i dotyczy ona 2\% podróżujących. Przyczyną przewlekłej biegunki są zakażenia pierwotniakowe [9].

Problemem coraz częściej występującym u osób wracających z podróży jest poinfekcyjny zespół jelita drażliwego (ang. post-infectious irritable bowel syndrome - PI-IBS). Pojawia się po mniej więcej pół roku od przebycia biegunki podróżnych. Zanotowano, że aż u 18\% osób w dalszym ciągu pojawiają się dolegliwości ze strony układu pokarmowego. Efektywne zapobieganie TD wydaje się ważnym zagadnieniem [10].

\section{Występowanie}

Kraje wysokiego ryzyka są zlokalizowane: w Azji, na Bliskim Wschodzie, w Afryce, w Ameryce Południowej i Środkowej (Meksyk).

Kraje średniego ryzyka obejmują: Europę Wschodnią, Afrykę Południową, niektóre wyspy karaibskie.

Kraje niskiego ryzyka to: Stany Zjednoczone, Australia, Kanada, Nowa Zelandia, Japonia, kraje Europy Północnej i Zachodniej [7].
W Azji, Afryce, Ameryce Południowej i Środkowej biegunka podróżnych doczekała się lokalnych nazw, takich jak „zemsta Faraona”, „galop gringo” lub „klątwa Montezumy" [11].

\section{U kogo częściej wystąpi TD?}

Problem ten częściej dotyczy osób podróżujących z krajów uprzemysłowionych do krajów rozwijających się strefy tropikalnej i subtropikalnej; turystów, którzy wcześniej nie podróżowali do krajów rozwijających się (w przeciwieństwie do osób, które często wyjeżdżały do regionów o wysokim ryzyku); osób, które nie zachowują ostrożności w jedzeniu i piciu; takich, którym przydarzył się epizod biegunki podczas ostatniej podróży; których czynniki genetyczne predysponują do występowania TD; osób dysponujących niskim budżetem podczas podróży oraz słabo przygotowanych do podróży; osób żyjących wśród mieszkańców regionu wysokiego ryzyka (np. wolontariusze) [12]. Biegunka podróżnych częściej występuje u dzieci poniżej 2. roku życia, a także u osób dorosłych od 20. do 30. roku życia. Do czynników predysponujących należą: długość pobytu, niska kwaśność żołądka, immunosupresja, wrzodziejące zapalenie jelita grubego, choroba Crohna [13, 14].

\section{Jak możemy zarazić się biegunką?}

Niepoddana odpowiedniej obróbce żywność i zanieczyszczona fekaliami woda są głównym zbiornikiem patogenów wywołujących biegunki podróżnych [7]. Do niebezpiecznej żywności zaliczamy sałatki, nieobrane i niedogotowane warzywa i owoce, surowe lub słabo dogotowane mięso, ryby i owoce morza, niepasteryzowane produkty mleczne. Nie należy: pić wody prosto z kranu, używać nieprzegotowanej wody do płukania zębów, dodawać lodu do napojów. Wiele osób uważa, że trudno jest stosować się do restrykcyjnej diety, co za tym idzie - aż 95\% podróżujących w ciągu kilku dni od przyjazdu łamie - przypadkowo lub celowo - zasadę „bezpiecznego” jedzenia i picia. Dodatkowo istnieje mało dowodów na korelację między przestrzeganiem diety, stosowaniem środków ostrożności i zmniejszonym ryzykiem TD, choć rozsądek podpowiada zachowanie ostrożności podczas wyboru żywności [15].

Jedzenie w restauracjach, spożywanie żywności od ulicznych sprzedawców, spożywanie zimnych sosów, żywności, która na początku jest gotowana, a następnie podgrzana - to wszystko zwiększa ryzyko wystąpienia TD [16]. Często nie zdajemy sobie sprawy, że ważniejsze jest to, gdzie jemy, niż to, co zjemy. Należy też pamiętać o skorzystaniu z płynu antybakteryjnego do rąk przed posiłkiem [15]. 


\section{Leczenie}

Do podstawowych działań podczas leczenia biegunki należy przede wszystkim zapobieganie odwodnieniu w gorącym klimacie dotyczy to głównie dzieci i osób w podeszłym wieku. W tym celu należy używać butelkowanej wody do picia. Pierwsze objawy biegunki łatwo można zniwelować za pomocą leków hamujących perystaltykę jelit, a także dobrze dobranymi lekami przeciwbakteryjnymi. Sposób dawkowania i podawania takich środków warto omówić wcześniej, podczas wizyty lekarskiej przed wyjazdem. Należy podkreślić, że około $50 \%$ przypadków ostrej biegunki związanej z podróżą ustępuje w ciągu 48 godzin [17].

Doustna szczepionka przeciwko cholerze zapewnia częściową ochronę przed bakteryjną biegunką podróżnych [18]. Niezależnie od etiologii zauważono, że częstość występowania epizodów związanych z biegunką zmniejszyła się o 23\% u turystów zaszczepionych WC-rBS. Podkreślić tu należy, że okres immunoprotekcji wydaje się krótszy od obserwowanego w przypadku cholery. Szczepione przeciwko TD według wskazań w części krajów powinny zostać m.in. osoby z predyspozycjami do zakażeń pokarmowych oraz biegunki o ciężkim przebiegu, w tym turyści stosujący przewlekle leki z grupy inhibitorów pompy protonowej lub immunosupresyjne, obciążeni przewlekłymi, zapalnymi schorzeniami jelit oraz małe dzieci. Szczepionka WC-rBS jest zarejestrowana w niektórych państwach do zapobiegania zarówno cholerze, jak i biegunce podróżnych wywoływanej przez Escherichia coli (ETEC). W Polsce szczepionka WC-rBS (Dukoral, Sanofi Pasteur) została zarejestrowana jako środek stosowany w profilaktyce cholery [10].

Profilaktycznie przed podróżą podaje się antybiotyki takie jak ciprofloksacyna lub rifaksymina. Przydatne mogą być zwłaszcza podczas krótkoterminowych podróży, ale wiążą się z zagrożeniami, np. wywołana przez Clostridium difficile biegunka jest związana z ciprofloksacyną [19].

Wszystkie osoby podróżujące do obszaru wysokiego ryzyka zachęcane są do samodzielnego leczenia TD antybiotykiem. Do tej pory 3 antybiotyki okazały się być skuteczne w skróceniu czasu trwania biegunki podróżnych. Należą do niech fluorochinolony (ciprofloksacyna lub lewofloksacyna), rifaksyminy (Xifaxan, Salix) i azytromycyny [12].

Fluorochinolony są najskuteczniejsze i często stosuje się je jako leki z wyboru u dorosłych. Pojedyncza dawka w kuracji 3-dniowej zazwyczaj jest wystarczająca, o ile nie występują objawy takie jak gorączka i krew w stolcu świadczące o zakażeniu szczepami inwazyjnymi. Zwrócić należy uwagę, że ze względu na ryzyko ogólnoustrojowych działań niepożądanych fluoro- chinolony nie powinny być stosowane jako preparaty pierwszego rzutu w prewencji biegunki [10]. Lek ten jest przeciwwskazany dla kobiet w ciąży i dla dzieci poniżej 15. roku życia [3]. Fluorochinolony są bardziej skuteczne niż rifaksymina w leczeniu biegunki spowodowanej przez szczepy Shigella [12].

Leczenie rifaksyminą w $90 \%$ przypadków, w tym w leczeniu TD, okazało się skuteczne. Lek ten ma mniejsze skutki uboczne i wiąże się z mniejszą ilością obaw wynikających z rozwoju oporności [12]. Rifaksymina działa na bakterie tlenowe i beztlenowe Gram-dodatnie i Gram-ujemne. Nie jest zalecana u kobiet w ciąży i u dzieci poniżej 12. roku życia. Nie wolno jej stosować w przypadku gorączki lub przy obecności krwi w stolcu [3].

Inwazyjne enteropatogeny bakteryjne są najbardziej prawdopodobnymi przyczynami biegunek podróżnych podczas podróży do Azji Południowej. Niektórzy eksperci medycyny podróży zalecają wyjeżdżającym do tej części świata zaopatrzyć się w azytromycynę do samodzielnego leczenia [12]. Można stosować ją u kobiet w ciąży i u dzieci [3].

Po rozpoczęciu leczenia antybiotykami biegunka trwa około 24 godzin (dla porównania: u osób przyjmujących placebo czas trwania biegunki wynosił 50-70 godzin). Leczenie antybiotykami jest zalecane we wszystkich przypadkach umiarkowanej biegunki [12].

Loperamid jest syntetycznym lekiem opioidowym i został zatwierdzony przez amerykańską Food and Drug Administration (FDA) do stosowania u dorosłych i dzieci w wieku powyżej 2 lat. Wydaje się być bezpieczny w większości rodzajów biegunki, choć jego stosowanie nie jest zalecane, gdy nie ma krwi w stolcu lub temperatura przekracza $38,5^{\circ} \mathrm{C}$. Loperamid jest skuteczny podawany samodzielnie lub w połączeniu $z$ antybiotykiem. Zalecaną dawką jest $4 \mathrm{mg}$ doustnie, a następnie $2 \mathrm{mg}$ po każdym luźnym stolcu, maksymalnie do $16 \mathrm{mg}$ na dobę u dorosłych. Korzystanie $z$ loperamidu nie jest zalecane $u$ kobiet $w$ ciąży lub karmiących piersią. Lek jest ogólnie dobrze tolerowany, ale czasem może powodować zaparcia, wzdęcia i uczucie dyskomfortu w brzuchu [20].

Wszechstronne zastosowanie, w tym w terapii i profilaktyce wielu chorób, znajdują probiotyki (dokumentowana jest skuteczność Lactobacillus rhamnosus oraz Saccharomyces boulardii). Najlepsze rezultaty odnotowano w terapii biegunek o zróżnicowanej etiologii. Biegunki podróżnych stanowią odmianę biegunek infekcyjnych, dlatego stosowanie probiotyków wydaje się być skuteczne w przypadku zminimalizowania nieprzyjemnych skutków choroby. Badanie Oksanena i wsp.przeprowadzone na grupie 800 turystów wykazało, że ryzyko wystąpienia biegunki u turystów suplementowanych probiotykiem zmniejszyło się w porównaniu 
z osobami przyjmującymi placebo. Innym problemem jest stosowanie antybiotyków, które zaburzają prawidłowy ekosystem bakterii jelitowych. Leki te niszczą oprócz chorobotwórczych mikroorganizmów wywołujących biegunkę także wysoce wrażliwe bakterie komensalne. Częstym powikłaniem po antybiotykoterapii jest biegunka poantybiotykowa występująca nawet u 40\% dzieci. Dlatego ważne jest, aby podczas przyjmowania antybiotyku podawać preparaty probiotyczne, które zmniejszają ryzyko wystąpienia kolejnej biegunki o około $50 \%$ [21].

\section{Należy skontaktować się z lekarzem, jeśli:}

- temperatura ciała przekroczy $39^{\circ} \mathrm{C}$,

- wymioty trwają dłużej niż 2 dni,

- $\quad$ objawy utrzymują się dłużej niż 5 dni,

- zachorują ciężarne, dzieci do 8. roku życia, osoby starsze $>65$. roku życia,

- $\quad$ chorobą towarzyszącą jest czerwonka [22].

\section{Profilaktyka}

Podróżnikom często radzi się, by zachowywali się zgodnie z zasadą, która brzmi następująco: Boil it, cook it, peel it, or forget it („Ugotuj, obierz lub zapomnij”). Najlepszym sposobem zapobiegania jest unikanie wątpliwej żywności lub napojów. Nie należy pić wody z kranu, chyba że została przegotowana, przefiltrowana lub chemicznie odkażona. Należy pić wyłącznie napoje butelkowane bez dodatków w postaci lodu. Nie wolno jeść owoców i warzyw, o ile wcześniej nie zostały obrane lub ugotowane, a także gotowanego jedzenia, które nie jest już gorące - takie pozostawione w temperaturze pokojowej jedzenie jest szczególnie niebezpieczne. Należy unikać: niepasteryzowanego mleka oraz innych produktów, które mogą być wykonane z niepasteryzowanego mleka (do takich produktów należą lody), żywności i napojów uzyskanych od ulicznych sprzedawców, surowego lub niedogotowanego mięsa lub ryb. Niektóre gatunki ryb mogą zawierać trujące biotoksyny nawet po ugotowaniu; w szczególności nie powinno się spożywać barrakudy. Inne ryby, które mogą zawierać toksyny, to seriola (ang. amberjack), okoń morski i wiele innych tropikalnych ryb rafowych [23].

Innym zaproponowanym przez naukowców podejściem do zapobiegania TD jest stosowanie probiotyków, gdyż nie wykazują one oddziaływania toksycznego na organizm. Jednakże tylko kilka środków probiotycznych okazało się być skutecznymi w randomizowanych badaniach klinicznych (Lactobacillus GG, Saccharomyces boulardii). Warto byłoby zainteresować się tym tematem i przeprowadzić specjalne badania, które pomogłyby poznać skuteczność probiotyków, ponieważ leki te mają niską cenę i doskonałe profile bezpieczeń- stwa i akceptacji, co czyni je idealnym rozwiązaniem dla turystów, którzy mogą je wykorzystać do samoleczenia (szczególnie polecane są osobom z grup wysokiego ryzyka, a więc kobietom w ciąży i dzieciom) [24].

\section{Wnioski}

1. Biegunka podróżnych jest najczęstszym problemem zdrowotnym osób podróżujących z krajów uprzemysłowionych do krajów rozwijających się o niskim standardzie sanitarnym. Szacuje się, że występuje u 30-70\% osób wyjeżdżających.

2. Najczęstszą przyczyną biegunek jest zakażenie Escherichia coli (ETEC), rzadziej do zakażenia dochodzi bakterią z rodzaju Campylobacter, Shigella, Salmonella. Pasożyty i wirusy są mniej powszechne w etiologii.

3. Ciężką biegunkę podróżnych rozpoznaje się u turysty, jeżeli w czasie wycieczki oddaje 3 i więcej płynnych lub półpłynnych stolców. Towarzyszy temu co najmniej jeden z wymienionych objawów: gorączka, nudności, wymioty, bóle brzucha, obecność krwi w kale lub bolesne parcie na stolec.

4. Zazwyczaj objawy pojawiają się w pierwszym tygodniu pobytu, a w ponad 90\% przypadków występują w ciągu pierwszych 2 tygodni.

5. Wiele osób uważa, że trudno jest stosować się do restrykcyjnej diety, co za tym idzie - aż 95\% podróżujących w ciągu kilku dni od przyjazdu łamie zasade „bezpiecznego" jedzenia i picia.

6. Do podstawowych działań podczas leczenia biegunki należy przede wszystkim zapobieganie odwodnieniu - w gorącym klimacie dotyczy to głównie dzieci i osób w podeszłym wieku.

7. Inną formą leczenia biegunek podróżnych jest podawanie antybiotyków, loperamidu oraz probiotyków.

8. Niezależnie od etiologii zauważono, że częstość występowania epizodów związanych z biegunką zmniejszyła się o 23\% u turystów zaszczepionych WC-rBS, która w Polsce zarejestrowana jest tylko jako środek stosowany w profilaktyce cholery.

\section{Piśmiennictwo}

1. Mianowany M, Bednarek-Gejo A, Skoczylas P, Głowacka A. Ocena poziomu wiedzy i świadomości studentów na temat zagrożeń biologicznych występujących w krajach tropikalnych. Probl Hig Epidemiol. 2012; 93 (2): 385-391.

2. Van Damme-Ostapowicz K, Krajewska-Kułak E. Standard edukacji pielęgniarskiej wobec pacjentów z zakresu medycyny podróży. Probl Piel. 2013; 21 (1): 1-6.

3. Chlabicz S. Antybiotyki dla osób podróżujących. Forum Med Rodz. 2008; 2; 3: 229-233.

4. Mach T. Biegunka podróżnych. Gastroenterol Klin. 2011;3; 3: 121-126. 
5. Ericsson CD, DuPont HL, Steffen R. Travel's diarrhea. Engl J Med. 2004; 350, 17: 1801-1804.

6. Szajewska H. Saccharomyces boulardii - aktualne dane naukowe. Prz Gastroenterol. 2012; 7 (6): 351-358.

7. Centres for Disease Control and Prevention, www.cdc.gov (data dostępu: 30.04.2015).

8. Paredes-Paredes M, Flores-Figueroa J, Dupont HL. Advances in the treatment of travelers' diarrhea. Curr Gastroenterol Rep. 2011;13, 5: 402-407.

9. Diemert DJ. Prevention and Self-Treatment of Traveler's Diarrhea. Clin Microbiol Rev. 2006;19, 3: 583-594.

10. Wroczyńska A, Nahorski WL. Profilaktyka cholery i biegunki podróżnych. Zakażenia. 2010; 2: 113-117.

11. (Dostępne w Internecie:) www.szczepieniadlapodrozujacych.pl (data dostępu: 30.04.2015)

12. de la Cabada Bauche J, DuPont HL. New Developments in Traveler's Diarrhea. Gastroenterol Hepatol. 2011;7, 2: 88-95.

13. (Dostępne w Internecie:) www.medycynatropikalna.pl (data dostępu: 30.04.2015).

14. Navaneethan U, Giannella RA. Definition, Epidemiology, Pathophysiology, Clinical Classification, and Differential Diagnosis of Diarrhea. Guandalini S, Vaziri H (red.). Diarrhea Diagnostic and Therapeutic Advances. New York: Humana Press; 2011. 1-33.

15. Leder K. Advising travellers about management of travellers' diarrhoea. Aus Fam Physician. 2015; 44, 1: 34-37.

16. Yates J. Travel's Diarrhea. Am Fam Physician. 2005; 71; 11 : 2095-2100.

17. McGregor AC, Wright SG. Gastrointestinal symptoms in travelers. Clin Med. 2015; 15, 1: 93-95.

18. (Dostępne w Internecie:) www.szczepieniadlapodrozujacych. pl (data dostępu: 30.04.2015).

19. Patel RP, Liang SY, Koolwal P, Kuhlmann FM. Travel advice for the immunocompromised traveler: prophylaxis, vaccination, and other preventive measures. Ther Clin Risk Manag. 2015; 11: 217-228.
20. de Saussure PH. Management of the Returning Traveler with Diarrhea. Ther Adv Gastroenterol. 2009;2; 6: 367-375.

21. Cichy W, Gałęcka M, Szachta P. Probiotyki jako alternatywne rozwiązanie i wsparcie terapii tradycyjnych. Zakażenia. 2010; 6: 2-8.

22. Küpper T, Schoeffl V, Milledge J. Biegunka podróżnych profilaktyka i leczenie w górach. Stanowisko Komisji Medycznej UIAA. 2008; 5: 1-11.

23. (Dostępne w Internecie:) www.mdtravelhealth.com (data dostępu: 30.04.2015).

24. Rendi-Wagner P, Kollaritsch H, Ericsson CD, Steffen R. Drug Prophylaxis for Travelers' Diarrhea. Clin Infect Dis. 2001; 34, 5: 628-633

Artykuł przyjęty do redakcji: 13.05 .2015

Artykuł przyjęty do publikacji: 15.09.2015

Źródło finansowania: Praca nie jest finansowana z żadnego źródła. Konflikt interesów: Autorzy deklarują brak konfliktu interesów.

Adres do korespondencji:

Ewelina Kimszal

ul. Jerzego Waszyngtona 23a

15-304 Białystok

tel.: 504476011

e-mail: ewelinak91@02.pl

Studenckie Koło Naukowe „Tropik”

Zakład Zintegrowanej Opieki Medycznej

Uniwersytet Medyczny w Białymstoku 